\title{
China's engagements on the african continent: interrogating its true mission and objectives on the continent
}

\author{
John Mamokhere \\ University of Limpopo, South Africa
}

\author{
Keywords \\ Africa-China's engagements, Afrocentricity, Economic engagement, Neo-colonialism
}

\begin{abstract}
China's engagement(s) throughout the African continent has met with mixed reactions from academics, politicians, civil society, and interest groups. In that regards, this paper questions the link between China-Africa, if this is a new form of colonialism or is China kind to the continent. Thus, this paper examines whether the debates regarding the nature of the China-Africa relations can be qualified or categorized as a new form of colonialism approach or not. Also, the paper analyzes the perception of academics, politicians, civil society and interested groups about the implications towards the ChinaAfrica economic cooperation and explains whether China is taking advantage of the weak African states in the name of South-South cooperation or playing the role of a contemporary substitute of the old colonial system.

The paper has adopted an Afrocentricity theory as a lens sometimes referred as a theory of social change that is initiated and better clarified by Asante Molefi Kete (1980 and 2003). Afrocentricity is an approach to the study of world history that focuses on the history of people of recent African descent. To achieve the aims of this paper, the author(s) benefited from Critical Discourse Analysis (CDA) of secondary data covering China's economic engagements in Africa. Conceptually, it is found that China has a large influence in Zambia over the mining industry. It is affirmed that China's investments in the mining sector control over $88 \%$. Therefore, it is concluded in this paper that China's presence on the African continent presents equal opportunities (economic development, e.g., employment creation) and threats (loss of Sovereignty, employment exploitation).

Thereafter, this paper recommends that African governments should be pro-active in order to exploit the potential opportunities. The paper also recommends that there should be an economic winwin cooperation as per China's African Policy (2006), which implies that there should be a mutual benefit.
\end{abstract}

\section{General Introduction}

A new form of colonialism commonly known as neo-colonialism can be defined as a new form of colonialism aimed at dominating and exploiting the countries in a more delicate form (Ardant, 1965:837). According to Nkrumah (1975:145), neocolonialism is also conceptually understood as the geopolitical practice of using capitalism, business globalization, and cultural imperialism to control a country, in lieu of either direct military control or indirect political control. However, "the increase in China's economic involvement in the African continent is questionably the most momentous development on the in the African continent today. One of the argumentative issues surrounding China-Africa relations involves investments. Even though, China and Africa have been trading with each other for centuries now. The level and intensity of their trading relationship have increased dramatically since 2000. The trends and patterns of trade between China and Africa suggest many possible impacts in Africa" (Kabuka, Bii, Ombaba, Ongeri, Arogo, and Omuya, 2012:529). It can be affirmed that China is the second biggest economic player around the world after the United States of America (USA). Thus, Botha (2006) indicates that China is trying to establish itself as an important power in the international level and is doing it using Africa, to uphold its views and policies with international multilateral organizations. In relations to China-Africa, Africa plays an imperative role in this regard, predominantly in organizations with "one country, one vote" arrangements. Thus, China tries to get African governments to secure African's huge mineral or other resources and as well as to gain support for its policies in the international arena. 
In-depth, China's engagement(s) within Africa is based on strategic political and economic considerations. It is, therefore, debated that China's manifestation on the African continent grants both opportunities (economic development, e.g., exchange of skills, employment creation and poverty) as well as threats (loss of Sovereignty and employment exploitation), thereafter, African governments should be pro-active to exploit the potential opportunities (Botha, 2006). To comprehend the relationship between China-Africa, one needs to evaluate both sides involved. Botha (2006) opined that China's engagement in Africa is not solely attributable to China's behaviour in Africa, but some of the blame should also be shifted to corrupt African governments or officials and elites or political groups who function in a framework of neo-patrimonial politics which increases corruption and mal governance in the continent. China has become Africa's largest trade partner, with many deals involving natural resources in exchange for building infrastructure and loans. China imports oil from Africa, as well as commodities such as timber, copper, and diamonds. China also exports processed foods, household products and other manufactured goods to African countries. This paper interrogates the implications of China's engagements or investments and developmental activities in African countries.

\section{Background of The Study}

The recent China's presence and growth reflects its wider emergence as a global power. With its rapid economic development as the world's second largest economy today and its rising role in the global geopolitical arena, the type of development path that China is pursuing, and the way it affects the rest of the world, even Africa, are increasingly heated debates all over the world. China-traditional Africa's friendship dates back to history (Michael, 2013:4). The Bandung Meeting, Indonesia, was a historic milestone to forge a strategic alliance with China and developing countries in 1955 and took into account its ties between China and Africa (Michael, 2013:4). The citizens of the Republic of China or Chinese leaders had to see the conference delegates face to face for the first time. This was an initial period. It later opened a window for China to give African countries and liberation movements economic investment), technological, political, and military support (Michael, 2013:4).

A new historical phenomenon arose drastically from the end of the Cold war and the collapse of the Soviet Union in the long-standing conventional ties between Africa and China. The changes and new technologies in the world, in Africa and in China have given an advantageous environment to the growth of ties between Africa and China. While Africa and China seem to have been unable to have more contrasting contexts. China has risen very quickly, bringing hundreds of millions out of poverty, rising its global footprint, and becoming a modern world power. While the marginalization of the global economy is still being overcome in most African countries and hampered by various growth issues, persistent poverty, high unemployment rates and other socio-economic problems (Michael, 2013:5).

\section{Statement of the Problem}

China's investments throughout the Africa continent has met with mixed reactions from academics, politicians, civil society, and interest groups. Scholars and civil society continue to question if this is a new form of colonialism or is China kind to the continent? According to Rapanyane and Shai (2020:1), China's arrival in the African continent in the early 2000s over the Forum on China-Africa Cooperation (FCAC) has signaled with numerous joint beneficial promises. Yet, there is still views that the China's arrival on the African continent was driven by itself national interests. Such interests were mainly on the continent's worth especially mineral resources, which are considered important for its economic success. Rapanyane et al., (2020) further indicate that this remark reflects that scholars and practitioners have a mixed or different understanding of China's engagement within Africa. For instance, it is argued that Chinese mining companies' functions in Africa countries such as Democratic Republic of Congo (DRC), Zambia and in other countries are not diverse to the early colonial masters who became to Africa mineral resources to grow their own nations at the costs of Africa's own development.

\section{Theoretical Perspective on China-Africa Engagement Afrocentricity theory}

This paper has adopted an Afrocentricity theory as the relevant theoretical framework in analyzing the relationship between China and Africa. An Afrocentricity theory sometimes referred to as 'the theory of social change' is an applicable theoretical guide that stands a good chance of analyzing African issues. 
This theory has been initiated and is better enlightened by Molefi Kete Asante in his book titled "Afrocentricity: The Theory of Social Change" in 1980 and 2003. Asante's book offers informative thought on dominance, power, racism, and the need to escape from victimization. The theory aimed at decolonizing the mind and confusion of Africans scholars. Therefore, Rapanyane (2019); Rapanyane (2020:58), opined that the theory has been seen as a relevant analytic tool because of its ability to furnish Africans with grounding, orientation and perspective which stands a good chance of liberating and decolonizing African minds from East/Western claimed universal and objective theories developed in the past to subject Africans to non-African analytic tools in African problems. This theory has been relevant in this paper primarily because there is a need for African countries to escape from victimization imposed by China's dominance.

\section{Research Methodology and Design \\ Research design}

No research study can take place without the research design. Research designs are imperative for the undertaking of any study. Kumar (2011) considers research designs as a procedural plan that academic scholars adopt in answering research questions. As for Pandey and Pandey (2015), they are the frameworks of the study that are utilized for the processes of collecting and analyzing the data. Qualitative approaches provide findings that are commonly detailed, rich, and offering ideas and concepts to inform your research. MacDonald and Headlam (2014) posit that qualitative has the potential to disclose the feeling of the people and also how they think without providing a numerical of the target population that feel or think that way. Research methodology, which was adopted for this study is qualitative. Thus, a qualitative design will be briefly discussed below.

\section{Qualitative design}

Bryman (2020) indicates that a qualitative research is a collection of social data that focuses on meaning thus providing valuable insights into the local perspectives of study populations. They can contribute to culturally specific and contextually rich data (Mack, et al., 2005). In the qualitative study, the researcher relies on the principles from interpretive or critical social science emphasis on the language of "cases and contexts" and of cultural meaning (Neuman, 2014). A qualitative study is underpinned on the logic that arises from ongoing practice while following a nonlinear research path (Neuman, 2014). The existing literature was systematically reviewed and synthesized. This process involved the review of peer-reviewed journal papers, books, government legislations, and internet sources. Similarly, to attain the aims of this paper, the author adopted a qualitative research approach whereby secondary data has been utilized. Therefore, the paper drew information from published articles, reports, newspapers, books, and other readily available material.

\section{Review of Related Literature}

This section provides an overview of related literature in China-Africa economic engagements.

\section{Forms of Neo-Colonialism in Africa}

To comprehend if China engagements in Africa is an honest engagement or is a form of new colonialism. It is important to understand different forms of colonialism. Therefore, the following forms of new colonialism would make it easy to understand the level or status we are with regards to colonialism status in Africa. Badi (1996:65), indicates that there are three forms of neo-colonialism in Africa, namely, real neo-colonialism, ultra-neo-colonialism, and auto-colonisation.

The (i) real neo-colonialism "is exercised by former European colonial powers which continue to maintain a relationship of dependency with their ancient colonies. Despite the countries' sovereignty, the neo-colonial powers have an important monopoly in decision-making. France is a supreme example of a real neo-colonial country. Through the medium of French scholars, diplomats and military forces, France maintains a steady political and military control over its former African colonies. African are obliged to consult the international issues with their colonial" (Badi, 1996:65).

"Prominent examples of the (ii) ultra-neo-colonialism are the United State, former Russia and China who did not colonise any African states but replaced the former colonial powers. While the United State propagated the economic imperialism, the Soviet Union and China effused the ideological imperialism 
(Badi, 1996:66). These new forms of colonial powers use economic and military aid as a means of getting support. Direct military interventions secure their economic and political interests".

"The third form (iii) auto colonisation is voluntary and is undertaken by the African elite students who study in the European, American and China universities and accept their values. Upon their arrival to the homeland, they become officials, military or administrative officers and abide by the neo-colonial rules. They contribute to the adoption of development models which result in exploitation" (Badi, 1996:67).

\section{Implications of China-African Engagements}

In order to understand whether China's engagements or investments are out of goodwill or imposes threats to the African continent, this paper will unpack the following implications, looking at both opportunities and threats of China's engagement in African countries. For this paper, the author will only examine economic engagements.

\section{Economic Engagements}

Eigen (2012) indicates that China's growing presence in Africa is one of the region's biggest stories, but even seasoned analysts cannot decide whether this booming relationship is good or bad for Africa. Critics say Chinese strategy is entirely self-promotional, aimed at maintaining access to Africa's precious mineral resources even when that means propping up odious governments. China's supporters claim the Asian superpower is strictly neutral and business-oriented, preferring to generate economic growth not a dangerous dependency on aid. China has certainly been contributing to Africa's economic growth, both in terms of trade, job creation, and transfer of skills and with building infrastructure. All over the continent, it has built roads, railways, ports, airports, and telecommunications (Eigen, 2012).

African Development Bank Groups (2012) indicates that China has increasingly become an important economic player in Africa. Chinese investments in Africa span across many sectors and are not confined to the Chinese government and large state-owned companies. Several private Chinese companies have also invested heavily in Africa especially in mining at Zambia and DRC to mention few. For example, Huawei, a Chinese leading global telecom services provider, has invested a total of USD1.5 billion and employs 4000 workers in Africa. According to African Development Bank Groups (2012), China's trade with Africa has also grown progressively during the past decade reaching United State Dollar (USD) 160 billion in 2011 from just USD 9 billion in 2000. China's share in Africa's total trade has been phenomenal, rising to $13 \%$ from 3\% a decade ago. The growth in China's interest in Africa has been driven by the desire for Africa's natural resources to sustain its rapid growth. Currently, China imports one-third of its oil from Africa and some of its investments are tied to resource mining. For example, Angola has exchanged its oil resources for infrastructure development. Nonetheless, Chinese interests in the region go beyond oil and other raw materials. This section will further look at the Foreign Direct Investments (FDIs) and Chinese mining companies that function in Africa. Hereafter, they are discussed.

\section{Foreign Direct Investments (FDIs)}

According to Wang (2002:119), since the mid-1990s China has been targeting developing countries for its investment's projects. Consequently, China has increasingly been seeking new investment opportunities in Africa, often entering into a joint venture with either local or foreign companies. Chinese firms have invested in various sector in Africa, including resources, transport, agriculture, and trade. Chinese firms have also increased their investments in construction, largely, through infrastructure development projects. For the most part, African government has welcome Chinese Foreign Investment (FDI) which provides capital that African continent desperately needs (Mills and Shelton, 2003:33). According to Wang (2002:194), Chinese foreign investment aims to invest in the targeted sector and industries that contributes to achieving China's overall aim at the expense of the African continent. This is evidence that China's engagement in Africa is not of mutual interest or out of goodwill but rather absorbing international power and recognition through Africa.

According to Nowak, 2016 cited in Martuscelli (2020:286), China-Africa trade has developed in the recent two decades and for several African countries, China is today one of the most imperative trade partners. Total merchandise trade looking at exports and imports among China and Africa has enlarged from USD 9 billion in 2000 to USD 175 billion in 2015,1 making China Africa's largest trade partner. The 
composition of the trade flows shows that China imports mostly raw materials from Africa, in particular oil, and some food products, while it exports a more diversified bundle of low-cost manufacture goods. Moreover, Martuscelli (2020:286) confidently indicates that Chinese Foreign Direct Investment flows to Africa increased from USD 200 million in 2000 to USD 2.2 billion in 2012, making China the largest developing country investor in the continent. Chinese aid initiatives in Africa in the form of economic or technical co-operation have also increased remarkably in the last decade.

According to Botha (2006:90), there are several implications involved with regards to Chinese financial assistance to African countries such as Zimbabwe, India, and Kenya in which it has commercial interests for developing infrastructure that will facilitate Chinese commercial involvement in those countries as well as carrying favours with African elites. It evident that china's foreign aid is connected to china's companies who are contracted to provides the service for which aid is needed. Thus, China gains political and economic benefits through financial assistance to Africa. According to Shelton (2001:118), claim that China has assisted African countries by providing relieving some of the African debts as a goodwill gesture. Moreover, Thompson (2005:22), believe that debt forgiveness or debt relief earns China considerable leverage among African countries, thereby securing and ensuring political support in the United Nation (UN) and another international forum. Above discussion about China-Africa investments, it is evidence that China investments in Africa impose threats to developing African countries who fail to pay back the loans. The countries also at risks of losing their independence to China.

\section{Chinese Mining Companies in Africa}

According to Africa advice (2019) and Rapanyane (2020:56), Chinese mining companies, which are functioning in Zambia are NCF Africa Mining Plc, Non-Ferrous Corporation Africa Mining Plc, China Beijing Soly Technology Co. Ltd and Chambishi Metals PIc. There are other Chinese companies which are owned by China Nonferrous Metal Mining Company (CNMC) operating in Zambia such as Luanshya Copper Mine, Jianchua Mining Group and/ Nickel City of China (Li, 2010). Others such as Collum Coal Mine are smaller and do not trade with London Metal Exchange but rather export their minerals back to China unlike CNMC (Li, 2010; Rapanyane, 2020:56). Therefore, out of all mines functioning in Zambia's mining industry, China has $88 \%$ in the mining industry (Rapanyane, 2020:56).

In 2011, the copper mines which are under China in Zambia were reported to have been contravening the Zambian mining acts. This manifested in the form of having poor safety and health conditions. To add, Chinese hatred towards Zambia's trade unions escalated this matter as there were also labour hours of 12 to 18 hours per day which are abnormal in terms of the labour law. During the same year, China's Zambian employees argued that they were victims of brutal working conditions that infringed both Zambian and international standards of working (Smith 2011; Rapanyane, 2020). Lubinda and Jian (2018: 218) indicate that earlier before 2011 incidents, Xiao Li Shan, and Wu Jian Huawho served as managers of one of the Chinese mines in 2010 was found guilty of attempting to kill by shooting at least 11 Zambian workers who were demanding (protesting) better wages in the Collum Coal Mine of the southern town of Sinazongwe (Southern Province of Zambia). Both also argued that these incidents did not hit them by surprise as China was internationally known of its substandard human rights records (Lubinda and Jian, 2018). Despite this, since it arrived in Zambia in 1998, China's mining companies have managed to set up about 14 subsidiaries of CNMC to explore Zambia's mining industry. They also created over 140000 jobs of which make them the biggest investors in the sector.

These mining companies were also able to fund inter alia; Sinozam friendship hospital (currently not operating) which is attested to offer free medical treatment to their employees together with their family members (Rapanyane, 2020). However, at the same time, "Director General of Zambian Development Agency, Patrick Chisanga, demonstrated the significance of China's investment in Zambia's mining sector as it supports Zambia's industrialization and contributes immensely to job creation" (Rapanyane, 2020). Despite China's positive contribution to the Africa continent, there is also negative, or threat imposed by the China's engagement in Africa such as victimization of people which the Afrocentricity theory aim to decolonize the mind and action of an African.

\section{Results}

This section provides a summary of results obtained from literature or critical content analysis. It is found that China-Africa engagements are mixed with both negative (threats) and positive (opportunities). 
It is discovered that China has a large influence in Zambia over the mining industry. It is affirmed that China's investments in the mining sector control over $88 \%$. This makes China companies in Zambia have dominance and controlling power in the mining industry. Therefore, it can be affirmed that Zambia and other Africa countries are at risk of losing their independence to China.

\section{Limitation of the Study}

Based on the nature of this study, the author(s) only focused on economic engagements between China and African continent. Even though, other studies, especially in international politics, they focus on both political and economic engagements as opposed to this study. By limiting this study to economic engagement, the author(s) was able to comprehend the implications that China investments have on the African continent. Therefore, the discussion was thoroughly limited to economic investments that China has on the African continent like FDI and Mining companies. For future research, the author(s) will focus on political engagements to understand policy implications and others.

\section{Conclusion and Recommendations}

This paper has examined the link between China and Africa to comprehend the mutuality between the parties involved. The paper focused mostly on China's engagement(s) in a form of economic engagements. Politically, Africa sees an opportunity to build an alliance with a growing world power which can support and promote the African agenda on the international level. For China, it sees an opportunity to get an African alliance for the legitimacy of its global influence as a rising power. Economically, Africa views China as an alternative source of investment and support for its economic development. So, it becomes clear that the China-Africa nexus is built on mutual interest and development. It has been evident that the China-Africa nexus have developed for the last decade with the spirit of partnership, where the collaboration has expanded in all areas of development inter alia; trade, investment, science, and technology. The paper also concludes by affirming that pragmatically, China's engagements or investments in Africa is a partly a new form of colonialism. By merely analyzing the three form of neo-colonialism. China-Africa relationship follows under ultra-neo-colonialism and auto colonialization which is based on economic interests and economic development. China's engagement with African is based on strategic political and economic considerations. It is, therefore, concluded that China's existence in Africa presents equally opportunities (economic development, e.g., employment creation, education, and health service) and threats (loss of Sovereignty), thereafter, African governments should be pro-active to exploit the potential opportunities.

Moreover, the paper further acknowledges the economic policy implications associated with the stakeholders. In that regards, the paper recommends that China should maintain its 2006 general principles and objectives of China's African policy. Hereunder are some of the general principles outlined as follows:

- Sincerity, friendship, and equality. China adheres to the Five Principles of Peaceful Coexistence, respects African countries' independent choice of the road of development and supports African countries' efforts to grow stronger through unity.

- Mutual benefit, reciprocity, and common prosperity. China supports African countries' endeavour for economic development and nation-building, carries out cooperation in various forms in the economic and social development, and promotes common prosperity of China and Africa.

- Mutual support and close coordination. China will strengthen cooperation with Africa in the United Nations (UN) and other multilateral systems by supporting each other's just demand and reasonable propositions and continue to appeal to the international community to give more attention to questions concerning peace and development in Africa. Above are some of the key principles of China's policy toward Africa.

The paper strongly urges China to maintain its objectives, mission without compromising its policy, Africa and should also avoid taking advantage of the vulnerable African countries. The relationship between China and Africa should be based on economic win-win cooperation.

\section{References}

Africa advice., 2019. The best 10 Mining Companies Corporations in Zambia 2019. Available at: 
https://www.africanadvice.com/Mining_Companies_Corporations/Zambia. (Accessed: 30/08/2020).

African Development Bank Groups., 2012. The Expansion of Chinese Influence in Africa-Opportunities and Risks. August 2012. Blog.

https://www.afdb.org/en/blogs/afdb-championing-inclusive-growth-across-africa/post/the-expansion-of-chineseinfluence-in-africa-opportunities-and-risks-9612/.

(Accessed: 09/06/2020).

Ardant, P., 1965. Le Neocolonialism: Theme, Myth Et Reality. Revue Françoise De Science Polities, Pp.837-855. http://www.persee.fr/web/revues/home/prescript/article/rfsp_0035-2950_1965_num_15_5_392883/ (Accessed : 07/08/2020).

Asante, M. K., 2003. Afrocentricity, the theory of social change (p. 50). Chicago, IL: African American Images.

Badi, M. K., 1996. El neocolonialismo en África: sus formas y manifestaciones. Africa América Latina, cuadernos: Revista de análisis sur-norte para una cooperación solidaria, (24), 63-68.

Botha, I., 2006. China in Africa: friend or foe? China's contemporary political and economic relations with Africa (Doctoral dissertation, Stellenbosch: University of Stellenbosch).

Bryman, A., 2012. Social research methods. Oxford: Oxford University Press.

China's African Policy., 2006. China's African Policy. Beijing: Ministry of Foreign Affairs, the People's Republic of China. Available at: https://www.fmprc.gov.cn/zflt/eng/zgdfzzc/t481748.htm (Accessed: 10/11/2020).

Eigen, P., 2012. Is China good or bad for Africa? October 2012. Blog. http://globalpublicsquare.blogs.cnn.com/2012/10/29/is-china-good-or-bad-for-africa.

(Accessed: 08/02/2020).

Kabuka, P. O., Bii, P., Ombaba, K. M. B., Ongeri, L., Arogo, P. A., and Omuya, J., 2012. A study on the impact of China's investments in Africa: the case of Kenya. Journal of Emerging Trends in Economics and Management Sciences, 3(5), 529-537.

Kumar, R., 2011. Research methodology: A step-by-step guide for beginners. London: Sage Publications Limited.

Li, P., 2010. The Myth and Reality of Chinese Investors: A case study of Chinese Investment in Zambia's copper belt. Available at: www.eisourcebook.org/cms/June 2013/Myth\& Reality of Chinese. (Accessed: 26/08/2019).

Lubinda, M., and Jian, C., 2018. China-Zambia Economic relations: Current developments, challenges, and future prospects for regional integrations. International Journal of Economics, Commerce and Management, United Kingdom, 6(1), 205-223.

MacDonald, S., and Headlam, N., 2014. Research Methods Handbook: Introductory guide to research methods for social research. United Kingdom: Centre for Local Economic Strategies.

Mack, N., Woodsong, C., Macqueen, K. M., Guest, G. N., and Namey, E., 2005. Qualitative Research Methods: A Data Collector's Field Guide. Family Health International.

Martuscelli, A., 2020. The economics of China's engagement with Africa: What is the empirical evidence? Development Policy Review, 38(3), 285-302.

Michael, F.H., 2013. Atlantic International University Honolulu, Hawaii January 2013.

Mills, G., and Shelton, G., 2003. From butterflies to take off. Asia-Africa trade and investment ties. Asia-Pacific and Africa realising economic potential.

Neuman, W. L., 2014. Social Research Methods: Qualitative and Quantitative Approaches (7th ed.). Hallo: Pearson Education Limited Harlow

Nkrumah, K., 1975. "Redefinition of Neocolonialism", Readings in African Political Thought, edited by Mutiso, GideonCyrus and S.W. Rohio, pp415-418. London: Heinemann.

Nowak, W., 2016. China-Africa and India-Africa trade in the years 2000-2014. Procedia Economics and Finance, 39, 140-146. https :/ / doi.org/10.1016/S2212-5671(16)30261-1.

Pandey, P., and Pandey, M., 2015. Research methodology: Tools and techniques. Buzau: Bridge Center.

Rapanyane, M. B., 2019. An Afrocentric exploration of Jacob Zuma's anti-Apartheidanti-Apartheid stance: The question of Israeli-Palestinian struggle. Journal of Public Affairs, 20(2), e2017.

Rapanyane, M. B., 2020. An Afrocentric analysis of the successes and failures of Chinese companies in the application of Corporate Social Responsibility in Zambia's Mining Sector. African Renaissance, 17(1), 55-73.

Rapanyane, M. B., and Shai, K. B., 2020. China's multinational corporations in the Democratic Republic of Congo's mining industry: An Afrocentric critique. Journal of Public Affairs, 20(2), e2046.

Shelton, G., 2001. China and Africa: Building an economic partnership. South African Journal of International Affairs, 8(2), pp.111-119.

Smith, D., 2011. Chinese mining firms in Zambia under fire for mistreating workers. The Guardian, 3, 2011.

Thompson, D., 2005. China's emerging interests in Africa: opportunities and challenges for Africa and the United States. African Renaissance, 2(4), pp.20-29.

Wang, M.Y., 2002. The motivations behind China's government-initiated industrial investments overseas. Pacific Affairs, pp.187-206. 